Rebecca Margolis

\title{
The Keneder Adler and Yiddish community life in Montreal, 1944
}


Rabbi Pinchas Hirschprung became a towering figure in the Montreal Jewish community during a time when Yiddish functioned as the Jewish lingua franca. In 1944, The Keneder Adler both serialized his memoir, Fun Natsishen Yomertol: Zikhroynes fun a Polit (From the Nazi Vale of Tears: Memoirs of a Refugee) and printed it in book form. This study offers a snapshot of this rapidly changing community of 1944 through a close study of its newspaper, The Keneder Adler, including coverage of the liberation of the Nazi death camps, community responses, and new local community educational initiatives.

Le rabbin Pinchas Hirschprung est devenu un personnage essentielle dans la communauté juive montréalaise à l'époque où le yiddish fonctionnait comme lingua franca juive. En 1944, le Keneder Adler sérialisait ses mémoires Fun natsishen yomertol: Zikhroynes fun a Polit (dans la vallée de larmes des nazis: mémoires d'un réfugié) et l'imprimait sous forme de livre. Cette étude offre un aperçu de cette communauté de 1944 alors en pleine mutation grâce à une étude approfondie de son journal, le Keneder Adler, y compris son reportage de la libération des camps de mort nazis, des réponses communautaires, et de nouvelles initiatives d'éducation communautaire locale.

Rabbi Pinchas Hirschprung became a towering figure in the Montreal Jewish community during a time when Yiddish functioned as the Jewish lingua franca, before the polarization between fray and frum, secular and Haredi. No doubt he was a regular reader of the city's Yiddish-language community newspaper, the Keneder Adler/Canadian Jewish Eagle, upon his arrival to the city in 194I. His connection to the newspaper, however, ran deeper: in 1944, the Keneder Adler both serialized his memoir, Fun Natsishen Yomertol: Zikhroynes fun a Polit (From the Nazi Vale of Tears: Memoirs of a Refugee) and printed it in book form. ${ }^{.}$His "Few Words of Justification" at the beginning of the published volume attributes the inception of the work to the Keneder Adler's founder and publisher, Hirsch Wolofsky, who had initially suggested the project upon hearing parts of Hirschprung's story. According to Hirschprung, while some members of the local Jewish community had opposed the idea of the book as demeaning for a rabbi of his stature, "I disagreed with them and, encouraged by my friend, Hirsch Wolofsky, I went to work as he suggested" so that all future generations would know what the Nazis had done to their ancestors. ${ }^{2}$ Hirschprung also acknowledges the support of its editor, Montreal Yiddish writer and musicologist Israel Rabinovitch, who penned the volume's introduction. This role was not out of the ordinary for Wolofsky's Keneder Adler: the newspaper supported consecutive generations of Yiddish writers in Canada by encouraging them to write and publish in its pages. ${ }^{3}$ The memoir itself underlines the importance of Yiddish newspapers in the lives of their readers as Hirschprung describes his joy at coming across a copy of Kovno's newspaper, Yidishe Shtime (The Jewish Voice) while in transit. ${ }^{4}$ 
I944 - the year of the publication of Rabbi Hirschprung's remarkable memoir marked a year of transition for the Montreal Jewish community. The country was at war in the largest military conflict it had ever encountered. The European Jewish heartland lay in ruins, and a trickle of survivors was making its way to Montreal. The Jewish population was acculturating to its adopted Canadian homeland, as reflected in Canadian census statistics indicating a steady shift away from Yiddish as a mother tongue, from a high of $96 \%$ in $193 \mathrm{I}$ to $76 \%$ in $194 \mathrm{I}$ and $51 \%$ in $195 \mathrm{I}$. As relative newcomers to Canada, Jews participated in the Canadian war effort at home as well as overseas. Montreal Jewry was expanding and evolving, even during what was arguably the greatest crisis world Jewry had ever faced. This study offers a snapshot of this changing community and its newspaper, the Keneder Adler, through a close study of the month leading up to the Jewish New Year, the Hebrew month of Elul corresponding to mid-August to mid-September 1944. This period reveals intersecting community responses both to the liberation of the first Nazi death camps and the new school year. August is also marked the last of roo instalments of Hirschprung's memoir, which had begun publication in May of that year.

Founded in 1907 by Montreal businessman Hirsch Wolofsky, the Keneder Adler (Canadian Jewish Eagle) became Canada's first Yiddish daily and served a mass readership in Montreal as well as throughout Canada. The country's two other major Yiddish newspapers, the Toronto Yidisher Zhurnal/Daily Hebrew Journal and the Winnipeg Dos Yidishe Vort/the Israelite Press, regularly reprinted articles and other items from the Keneder Adler. The Keneder Adler's circulation was I8,000 in I94I, with each copy generally shared by multiple readers within a population of some 169,000 Canadian Jews. ${ }^{5}$

As a mass circulation daily newspaper, the Keneder Adler offers an indispensable source for understanding Canadian Jewry as a window into multiple aspects of the Canadian Jewish experience that evolved simultaneously: politics, history, literature, theatre, and others. Its pages indicate that during the years leading up to and during the Second World War, its readers were extremely well informed about world events in general and the fate of European Jewry in particular. In 1944, coverage of what later came to be known as the Holocaust was ubiquitous and multifaceted in the Canadian Yiddish press. The destruction of European Jewry under the Nazis was the story in all facets of the country's three major Yiddish newspapers in front page news, editorials, essays, literary supplements, advertisements for fundraising, and other expressions of local activism. In contrast to studies such as None Is Too Many which focus on the wide-ranging but unsuccessful efforts of the local community to lobby the Canadian government to allow in Jewish refugees, the Yiddish press reveals diverse grassroots mechanisms employed by the Jewish community to aid their European brethren in such fundraising campaigns and the collection and dissemination of information to help reunited shattered families. The debates of the 
last three decades about how much allied countries such as Canada knew about the events of the Holocaust exists outside of the Yiddish press. Unlike the coverage of the Holocaust in the mainstream press, which underplayed the Jewish identity of the victims, the Yiddish press both mourned the losses of its own, underlined the importance of rebuilding, and celebrated the rare victories. For example, the story of the 1944 "Iberian/Lisbon Refugees," the subject of Jack Lipinsky's study in this issue," dominated the pages of the Keneder Adler as well as its sister newspapers in Toronto and Winnipeg. What emerges in the dozens of articles on the story of these fourhundred Jewish refugees - from the announcement of each of the three planned voyages through their settlement in their new homes across Canada - is a Jewish community for whom this successful community activism significantly buoyed the newspaper's writers and readers. ${ }^{7}$

During the chosen time period of mid-August to mid-September 1944, one finds the pages of the Keneder Adler dominated by the khurbn, or what would become known as the Holocaust. The dominant story was Majdanek, the first of the Nazi death camps in Poland to be liberated by the Red Army. By the end of August, coverage of Nazi atrocities had made the front page of the New York Times, with Jews listed among numerous other ethnic groups as victims. For the writers and readers of the Keneder Adler, this was without question a Jewish story. A correspondent from Lublin, Raymond Davis, offers a lengthy, eyewitness account of the recent liberation of the Majdanek death camp and the acts of atrocity committed against innumerable Jews, including photos of the crematoria and mass graves, and many other stories followed (Sept. I). ${ }^{8}$ Over the next two weeks, the newspaper offered firsthand accounts of the liberation of the death camps in Poland - Majdanek, Belzec, Sobibor, and Treblinka with a focus on its Jewish victims (Sept. 4, 6, I2, and I7). Keneder Adler staff writer Israel Medresh penned an article that reveals his own shock and horror at the emerging news: "Naye shoyderlekhe eyntslheytn fun di natsishe toytn lagern/New Gruesome details of the Nazi Death Camps" (Sept.8).

What might be surprising, however, is the placement of these stories: they do not make front page headlines. Rather, the primary headline is always taken up by news of the war - in particular, the activities of the Canadian Armed Forces. Scholars such as Laurel Leff have pointed to the problematic "buried" placement of stories about the Holocaust in major newspapers such as the New York Times. The placement of these stories in the Adler, in contrast, indicates more about newspaper norms derived from wartime Canadian censorship of potentially sensitive military information than any attempt to downplay the events. While Army censors operated overseas, local censorship was carried out by civilian censors or by newspapers themselves; as Mark Bourrie's study of wartime censorship suggests, newspaper self-censorship did more to shape the control of information than the activities of the censors. ${ }^{9}$ Furthermore, the placement of a story in the Yiddish press did not necessarily indicate how it 
was received. The Keneder Adler's regular readers knew how to read their Yiddish newspaper: they may have read or skimmed the largest headline, which was reserved for government-approved news of the war effort, and then moved on to other news items or editorials, or a favourite feature such as the daily serialized novel, "Libe iz Blind," (Love is Blind); the weekly Di Literarishe Vokh (Literary Week; Fridays); Di Froyen Opteylung (Women's Section); the humour column, Vitsn un Shpritsn; or the Ayer Gezunt (Your Health) column. No reader could have missed the allencompassing story of the destruction of European Jewry as readers of mainstream newspapers might have; it permeated every aspect of the newspaper. As one example of many, the Women's Section featured news of women working with the Red Cross in war-torn Europe next to recipes for cornflake cookies (Sept. 5). It was this quest for information and perspective among readers that caused the Adler's circulation figures to increase during the war years, despite an overall decline in Yiddish language use.

What sets the Keneder Adler and other Yiddish newspapers apart from their mainstream counterparts is the scope of the coverage as well as the activist responses of the writers and readers. The appeals of the above-mentioned correspondent from Lublin to world Jewry for aid immediately motivated the Canadian Jewish Congress to establish a community-wide campaign to tackle the situation of the liberated Jews (Sept. I, 3, and I2). A front-page story details a delegation traveling to Ottawa regarding help for the Jews of Lublin (Sept. 8). Local poet J. I. Segal authored compelling essays calling for renewed unity and strength in the face of Nazi atrocities (Sept. I and 5). Ongoing emergency campaigns called for funds and clothing to send to the "remnants" of Polish Jewry. The newspaper also offered extensive coverage of the meeting of the United Nations Relief and Rehabilitation Administration (UNRRA) held in Montreal, and underlined the critical role of a Jewish lobby in lending support to European displaced persons, a majority of whom were Jews. On a grassroots level, one finds announcements from organizations coordinating city-wide campaigns to collect clothing for Jews in Poland and other recently liberated countries (Sept. Io). An open letter to Jews "who are spending the high holidays in hotels in the country" proclaims that given the horrendous recent news from Nazi-liberated lands, no one is exempt from his or her duty to help collect funds for the Jews suffering in the war; it calls for everyone to take part in the "Kol Nidre appeal committee" (Sept. I4). Even the Adler's weekly feature for its youngest readers, "In Kinderland" (Children's Land), responded to the liberation of Nazi death camps with both mourning and a message of hope in J.I. Segal's poem, "Rosh Hashanah 1944" (Sept. 14):

fun unter di khurves, un fun di ruinen,

krikht aroys a grezl tsit zikh un vil grinen. 
shteyn af shteyn der khurbn,

ash un shtoyb un tsigl, -

nor di hofnung, mintert

ir farshvakhtn fligl. ${ }^{10}$

(From under the wreckage and from the ruins a shaft of grass emerges, stretches and wants to blossom. The destruction is stone, ash, dust and brick, but hope flutters her weakened wing.) $)^{\mathrm{II}}$

Community activism during this time of upheaval and change took many forms. The Yidishe Folksbibliotek (Jewish Public Library) appears as a bastion for Yiddish, a role it would take on increasingly as Yiddish language use began its steep and steady decline after 1945. During a visit the Folksbibliotek, New York Yiddish poet and writer Avrom Reyzen (Abraham Reisin) expressed his thoughts in a message in the guest book:

geven in ayer institutsye, gezen bay di tishn yidn leyenen yidishe bikher, gezen di bikher - alerley bikher. gezen un nokh mer zikher gevorn in der tsukunft fun undzer vort, undzer shprakh. der bazukh bay aykh hot angefilt mayn vezn mit mutikayt un freyd.

(I was in your institution, saw people (lit: Jews) reading at the tables, saw the books, all sorts of books. Saw it and felt more certain of the future of our word, our language. The visit with you filled my being with courage and joy). (Sept. I)

The article goes on to connect Reyzen's remarks - which express "dem optimizm fun folk," the optimism of the people - with the Library campaign for a new building which had begun two weeks earlier (Aug. I8 and Sept. 7). This campaign took place alongside discussion around the Yiddish language itself as a measuring stick for Jewish continuity in a time of flux and uncertainty. Keneder Adler staff writer, historian B.G. Sack, penned a lengthy article about the languages of Canadian Jews based on Canadian census statistics where he concludes that Yiddish is alive and well as the language that a vast majority of Canadian Jews have grown up with and continue to use today (Sept. 3).

The area where one encounters the most dynamic and wide-ranging Jewish community activity is children's education. In the daily "In gezelshaftlekhn lebn" (Community Life) column, one finds dozens of announcements for a variety of supplementary schools as well as established and new Jewish parochial schools offering Jewish and secular studies under the same roof. This parochial school model, which offered an alternative to day school education in the Protestant schools with supplementary Jewish education, would become the dominant mode for Jewish 
education in the city but it was still relatively new in the 1940s. With the ongoing support of the Keneder Adler, the two labour-Zionist Jewish schools founded during the First World War - the Peretz Shul and the Yidishe Folks Shul - had established their parochial schools in 1927 and 1942 respectively. They also continued to offer supplementary school education: An open letter from the folks shul to parents urged them to register their offspring at the same time as the English schools so that the children would not perceive their Jewish educations as less important (Sept. 3). The Socialist Arbeter Ring (Workmen's Circle) School offered classes to ensure that "children would feel connected to the Jewish svive (milieu)," as well as a mandolin orchestra and girls' dance troupe (Sept. 15). The Morris Winchevsky School, which functioned under the aegis of the Communist-affiliated United Jewish People's Order (UJPO), advertised Jewish day school education at all grade levels, including a new kindergarten (Sept. 3). Meanwhile, further to the right of the spectrum, the Talmud Torah opened a parochial high school, the first of its kind in Canada (Aug. 22 and Sept. 3).

A relatively more recent development occurred among the Lubavitch Hasidim, whose ranks had been augmented in I94I by the arrival of nine Yeshiva students who had fled Poland via Shanghai in October of that year alongside Rabbi Hirschprung. They had immediately set to work augmenting education in the Montreal Jewish community in continuity with ventures they had been forced to abandon in their escape from the Nazi onslaught. On September I, one finds a large ad that reads,

yidishe eltern!

In di teg fun khezhbn hanefesh git zikh op a rekhenung vegn der ertsiyung fun ayer kind! gedenkt az in guter yidisher traditsionel-religiezer ertsiyung ligt der goyrl fun ayer kind un fun gantsn yidishn folk.

(Jewish parents!

In these days of soul-accounting, give reckoning about the education of your child! Remember that the fate of your child and all of the Jewish people lies in a good, traditional-religious education).

The ad concerns the opening of a new parochial elementary and high school for the Yeshivath Tomchei Temimim Lubavitch, which would offer secular as well as Jewish subjects. Established by Rabbi Aryeh Leyb Kramer almost immediately upon his arrival from Shanghai, the Yeshiva represented the Montreal branch of a network of Tomchei Temimim yeshivas established under the direction of the Lubavitcher Rebbe (Rabbi Yosef Yitzchak Schneerson): Kramer had previously established yeshivas in Poland as well during his sojourn in Shanghai. ${ }^{12}$ What is noteworthy here is not just the fact of the school's establishment as the first yeshiva in Canada and the site of the country's first rabbinical ordination, ${ }^{13}$ but the model adopted by the 
school, which presents itself in the same terms as the already existing day-schools as a "parochial school." Yeshivath Tomchei Temimim Lubavitch was not alone: Yeshiva Merkaz Hatorah, another institution of Jewish learning established by non-Hasidic (Mithnagdic) Orthodox Jews who had arrived on the same ship in 1941, announced that it had just moved into a new building on St. Joseph Boulevard in the heart of the Jewish neighbourhood and reported that it was attracting students from across Canada. It, too, adopted the parochial school model where secular and religious subjects appeared side by side, and boasted a new "English department." One also finds a variety of ads from other traditionalist schools such as Beys Dovid, Bney Yakov, and others. These Ultra-Orthodox schools employed similar rhetoric in addressing the parents: "Remember that the fate and future of your children lies in your hands. If you want to see a generation of true Jewish children filled with the spirit of Torah and Fear of God (toyre un yiras shomayim), register them right away..." (Aug. 28).

Multiple notices by these many schools address parents directly with varying degrees of urgency, in part because there were so many options to choose from. But there is also something deeper: a discourse around bringing Jewish values into a changing world, whether they be linked to culture like the more leftist schools, or Torah, like the schools further to the right on the spectrum. Jewish parents were invited to participate in the active transmission of Jewish identity to a new generation.

Here we see Montreal standing out in the wider Canadian and North American contexts. In Ontario, for example, most Jewish children continued to receive their Jewish educations in supplementary schools into the 1970s. ${ }^{14}$ Scholars point to a rapid expansion of Jewish day school education as a major area of change in North American Jewish life in the postwar era. Randal Schnoor's study, "The Contours of the Canadian Jewish Community," links the expansion of Jewish community infrastructure with postwar prosperity."15 Rona Sheramy's study of American Jewish Education after 1945 explains the marked increase in Jewish school enrollments that began in the 1940s: "In a sense, Jewish educational institutions became surrogate families and homes in the realm of Jewish life."16 In contrast, the wartime activity we see in Montreal predates these developments, and must be read through a different lens. Not only does it indicate a thriving and expanding community, including a newly augmented Haredi segment, but one building for its own future. Perhaps most importantly, this cultural activism offered a community response to the crisis of the Holocaust. It represented a form of resistance and activism alongside fundraising campaigns for Polish Jewry.

Overwhelmingly, the tone of the Keneder Adler in the month leading up to Rosh Hashana of 1944 was one of optimism. Aside from vociferous ongoing battles in the area of kashres (kosher food), Jewish communal life in Montreal appears as forward-looking and dynamic, full of hope for the future. The task of rebuilding what 
remained of a shattered Eastern European Jewish civilization was already underway.

Rabbi Hirchprung arrived in a Montreal to a vibrant and multifaceted Jewish cultural life, as expressed in its Yiddish-language daily newspaper. Jewish Montreal in 1944 was mourning terrible calamities in Europe while simultaneously building for a stronger future. As founder and longtime head of the Bais Yaakov (Beth Jacob) School for girls in Montreal (established in 1953 and renamed Bais Yaakov d'Rav Hirschprung after his death in 1998), the topic of education was near and dear to his heart. He would no doubt have been buoyed to see the wealth of Jewish community activity in the pages of the Keneder Adler, in particular the expansion of Jewish and particularly Haredi education in his newly adopted city.

1

To access a digitized version of the Yiddish text, see http://www.yiddishbookcenter.org/ collections/yiddish-books/spb-nybc207731/ hirschprung-p-fun-natsishen-yomertolzikhroynes-fun-a-polit/spb-nybc207731.

\section{2}

Pinchas Hirschprung, The Vale of Tears, translated into English by Vivian Felsen (Toronto and Montreal: Azrieli Foundation, 2016), xxvii.

\section{3}

See chapter 2 of Rebecca Margolis, Jewish Roots, Canadian Soil: Yiddish Culture in Montreal, 1905-1945 (Montreal and Kingston: McGill-Queen's University Press, 2011), 39-74.

\section{4}

Pinchas Hirschprung, The Vale of Tears, 204.

5

"Statistics of Jews," American Jewish Year Book, 1946-1947, http://www.ajcarchives.org/ AJC_DATA/Files/1946_1947_13_Statistics.pdf.

\section{6}

Jack Lipinsky, "1944: a Preview of Much of What Would Follow" Canadian Jewish Studies XXVII (2018).

\section{7}

For a more in-depth analysis of this point, see Rebecca Margolis, "A Review of the Yiddish Media: Responses of the Jewish Immigrant Community in Canada." In Ruth Klein, ed., Nazi Germany, Canadian Responses (Montreal and Kingston: McGill-Queen's University Press, 2012), 114-143.
8

Raymond Davis, “Nito di pen tsu kenen shildern shreklekhn masnshtob fun Hitlers farbrehn kegn Yidn," Keneder Adler, 1 September 1944, p. 2.

9

Mark Bourrie, The Fog of War: Censorship of Canada's Media in World War II (Toronto: Key Porter Books, 2011).

10

J.I. Segal, "Rosh hashone 1944," Keneder Adler, 14 September 1944.

11

Rebecca Margolis, "Hitler in Kinderland: Holocaust Writing for Children in the Canadian Yiddish Press: 1938-1945." In The Holocaust and World War II: In History and In Memory, ed. Nancy Rupprecht and Wendy Koenig (Newcastle upon Tyne, UK: Cambridge Scholars Publishing, 2012), 130-156.

12

Janice Arnold, "Rabbi Leib Kramer Commemorated," Canadian Jewish News, 9 December 2010, http://www.cjnews. com/news/canada/rabbi-leib-kramercommemorated, www.youtube.com/ watch?v=S8RPn1Qti18.

13

"First Smicha Ceremony in Canada," https:// www.youtube.com/watch?v=S8RPn1Qti18.

14

Alex Pomson, “Jewish Day-School Growth in Toronto: Freeing Policy and Research from 
Conventional Sociological Wisdom," Canadian Journal of Education 27, no. 4 (2002): 386.

15

Randal F. Schnoor, "The Contours of Canadian Jewish Life," Contemporary Jewry 31 (2011): 183.

16

Rona Sheramy, “"'Resistance and War”: The Holocaust in American Jewish Education, 1945-1960," American Jewish History 91, no. 2 (2003): 194. 